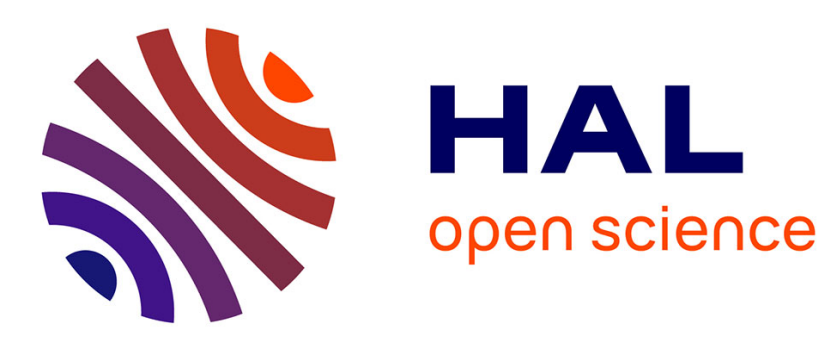

\title{
Vigilance patterns of wintering Eurasian Wigeon: female benefits from male low-cost behaviour
}

Steven J. Portugal, Matthieu Guillemain

\section{To cite this version:}

Steven J. Portugal, Matthieu Guillemain. Vigilance patterns of wintering Eurasian Wigeon: female benefits from male low-cost behaviour. Journal für Ornithologie = Journal of Ornithology, 2011, 152 (3), pp.661-668. 10.1007/s10336-010-0641-6 . hal-00659907

\section{HAL Id: hal-00659907 https://hal.science/hal-00659907}

Submitted on 14 Jan 2012

HAL is a multi-disciplinary open access archive for the deposit and dissemination of scientific research documents, whether they are published or not. The documents may come from teaching and research institutions in France or abroad, or from public or private research centers.
L'archive ouverte pluridisciplinaire HAL, est destinée au dépôt et à la diffusion de documents scientifiques de niveau recherche, publiés ou non, émanant des établissements d'enseignement et de recherche français ou étrangers, des laboratoires publics ou privés. 
2 VIGILANCE PATTERNS OF WINTERING WIGEON: FEMALE

3 BENEFITS FROM MALE LOW-COST BEHAVIOUR

4

$5 \quad$ Steven J. Portugal ${ }^{1 *}$ and Matthieu Guillemain ${ }^{2}$

6

$7{ }^{1}$ The Centre for Ornithology, School of Biosciences, College of Life and Environmental

8 Sciences, The University of Birmingham, Edgbaston, Birmingham, B15 2TT, UK. (+44

$9 \quad 1214145474)$

10

$11{ }^{2}$ Office National de la Chasse et de la Faune Sauvage, CNERA, Avifaune Migratrice, La 12 Tour du Valat, Le Sambuc, 13200 Arles, France.

13

$14 *$ To whom correspondence should be addressed: S.Portugal.1@ bham.ac.uk

15

16 Keywords

17 female benefit; mate guarding; male constraint; male investment; vigilance; Anas penelope 18

19 Short title

20 Female benefits from male vigilance

21

22 Word Count: 4, 667

23

24

25 


\section{6}

\section{Abstract}

Increased vigilance in male animals has been attributed to mate guarding (male investment hypothesis), secondary sexual characteristics increasing predation risk (male constraint hypothesis) or for benefit to the female (female benefits hypothesis). We studied Eurasian wigeon Anas penelope while they grazed on dry land, a 'risky' foraging situation, at two points during the winter period (pre and post pair formation) to assess if their behaviour was more consistent with one of these three hypotheses. Males were always highly vigilant, and vigilance increased markedly in more risky situations (smaller groups, higher distance from water). Mean male vigilance only changed to a minor extent from the pre- to the post-mating periods. Conversely, female vigilance significantly decreased after pairing, and was then significantly lower than that of males. Prior to pairing, males and females had similar rates of vigilance bouts. Overall, our findings suggest that higher vigilance in male wigeons in this instance is best explained by the female benefits hypothesis. Because the wigeons were foraging on land and were highly vigilant, even when unpaired, the females could actually benefit from the males vigilance without males investing more time in vigilance. In such a situation, paired males rely on 'low-cost vigilance' whereby vigilance serves as a safety mechanism while simultaneously benefiting the female.

\section{Zusammenfassung}

\section{Wachsamkeitsmuster bei überwinternden Pfeifenten: Weibchen profitieren von} „Kosten-effizientem“ Verhalten der Männchen

Besonders hohe Wachsamkeit männlicher Tiere wird in der Regel mit einer von drei Hypothesen erklärt: dem Bewachen ihrer Weibchen (male investment hypothesis), als sekundäres Geschlechtsmerkmal verbunden mit erhöhtem Risiko, erbeutet zu werden 
53 (male constraint hypothesis), oder zum Nutzen der Weibchen (female benefits

54 hypothesis). Wir untersuchten eurasische Pfeifenten (Anas penelope) beim Grasen auf

55 trockenem Land, einer risikoreichen Art der Nahrungssuche. Die Beobachtungen

56 fanden zu zwei Zeitpunkten während der Winterperiode (vor und nach der

57 Paarbildung) statt, um zu prüfen, ob ihr Verhalten eine der drei Hypothesen speziell

58 unterstützte. Die Männchen waren die ganze Zeit über sehr wachsam, und ihre

59 Wachsamkeit stieg in risikoreichen Situationen (in kleineren Gruppen, oder weiter

60 entfernt von Wasser) noch spürbar an. In der Zeit vor der Balz bis zu der Zeit danach

61 stieg die mittlere Wachsamkeit der Männchen kaum an, während im Unterschied dazu

62 die Wachsamkeit der Weibchen nach der Paarung deutlich nachließ und dann

63 signifikant niedriger als die der Männchen war. Vor der Paarbildung zeigten

64 Weibchen und Männchen ähnlich häufige Kurzphasen der Wachsamkeit. Unsere

65 Untersuchungen legen nahe, dass im vorliegenden Fall die erhöhte Wachsamkeit

66 männlicher Pfeifenten am besten von der „female benefits hypothesis“ erklärt wird.

67 Weil die Pfeifenten an Land auf Nahrungssuche gehen und dabei besonders im

68 unverpaarten Stadium außerordentlich wachsam sind, konnten die Weibchen von der

69 Wachsamkeit der Männchen profitieren, ohne dass diese Extra-Zeit dafür aufwenden

70 mußten. Die verpaarten Männchen begnügen sich mit dieser Kosten-effizienten

71 Wachsamkeit (low-cost vigilance), wobei diese als ein Sicherheitssystem dient, das

72 gleichzeitig den Weibchen nutzt. 


\section{Introduction}

75 The role of vigilance and the factors affecting vigilance levels are among the central questions of behavioural ecology (e.g. Krebs and Davies 1993). While vigilance in animals can typically have an anti-predator role, it may also be directed towards conspecifics, for example to avoid kleptoparasitism or to copy the behaviour of others (reviewed in Elgar 1989; Lima 2009). In paired males, vigilance may additionally be used to monitor the behaviour of competing other males (e.g., Dahlgren 1990). In many species, especially birds, males show distinct and conspicuous secondary sexual characters. While these may have a crucial role in sexual selection processes, such characters may also make males more visible to predators than females of the same species. Paired males may then be more vigilant than females because they face a greater predation risk when in breeding plumage, not just because they guard their mate (e.g., Lendrem 1983; Hart and Freed 2004). Lastly, males may use vigilance behaviours to enhance female survival and to allow females more foraging and resting time to enhance nutritional status and fecundity (e.g. Thompson and Popko 1981; Lamprecht 1989; Artis and Martin 1995; Weibe and Martin 1988; Rodway 2007a), with many studies reporting increased foraging times for the female when accompanied by a mate (e.g. Gauthier 1987). Furthermore, evidence suggests that male vigilance is important to females in mate selection, as females will preferentially select vigilant males (Dahlgren 1990; Choudhury and Black 1993; Pizzari 2003).

These possible causes of paired male vigilance have been commonly termed the "male investment", "male constraint" and "female benefits" hypotheses, respectively (e.g., Guillemain et al. 2003; Squires et al. 2007). The extent to which vigilance of males and females in a given species is more consistent with one or the other hypothesis may theoretically depend upon environmental conditions, though this 
99 has never been properly tested. Ducks are good model organisms to study vigilance

100 behaviour patterns, because they are subject to frequent attacks by predators

101 (including during daylight hours, Guillemain et al. 2007a), they are highly gregarious

102 and form pair-bonds anew during each winter period that are maintained for a long

103 time before the breeding season itself, during spring (Mayhew and Houston 1989; see

104 however Mitchell 1997 for evidence of occasional re-mating over successive years in

105 this species). In waterfowl, such pairing in late autumn or early winter is considered to

106 be adaptive: paired birds indeed get dominant status within the flock which provides

107 better access to food (e.g. Johnson and Rohwer 1988; Black 2005), and for the male a

108 early pairing should translate into higher eventual breeding probability if sexual

109 competition for mates exists among individuals (e.g. Rohwer and Anderson 1988;

110 Oring and Sayler 1992; Bowler 2005). This in turn may allow paired females to

111 improve body condition, sensu the female benefits hypothesis, which is likely to

112 translate into higher breeding success (Guillemain et al. 2008). For example, Lercel et

113 al. (1999) demonstrated that female ducks that lose their mate after pairing during

114 winter experienced lower subsequent breeding success, hence demonstrating the

115 fitness benefit of early pairing in such species. Squires et al. (2007) determined for

116 harlequin ducks (Histrionicus histrionicus) that male vigilance could be explained by

117 the female benefits hypothesis, because unpaired males were less vigilant than paired

118 males despite having the same plumage, although this does not rule out the male

119 investment hypothesis. This is the opposite to what would be expected if the vigilance

120 was a result of male constraint. In common eiders (Somateria mollisoma), conversely,

121 it was concluded that male vigilance was primarily for paternity assurance, because

122 widowed females foraged at the same rate as prior to the loss of their mate, and

123 maintained body mass and clutch size which was comparable with previous breeding 
124 seasons when paired (Hario and Hollmén 2004): females eiders had not been

125 benefiting nutritionally from having a mate.

During winter, previous studies of Eurasian wigeon Anas penelope have

127 demonstrated a significant difference in the length of time and frequency of vigilance

128 behaviour between the sexes during winter (Mayhew 1987). At this time males are

129 generally more vigilant than females (see also Goodburn 1984; Baldassarre and Bolen

130 2006). An earlier study in an acknowledged safe environment (mixed feeding flocks with

131 Brent Geese Branta bernicla L on large and open Zoostera sp. beds of the Exe Estuary,

132 UK, where predators were few) suggested that vigilance of male wigeons could be best

133 explained by the male investment hypothesis (Guillemain et al. 2003). This is because

134 males showed an increase in vigilance behaviour after pairing, not when they acquired

135 their brighter breeding plumage, and female vigilance rate did not differ between pre- and

136 post-pairing. In the present study, we also aimed to compare the vigilance levels of male

137 and female wigeons before and after the main period of pair formation, but in a less safe

138 environment in which birds were grazing on dry land, away from water. In such situation,

139 foraging wigeon use open water as a refuge in case of disturbance or predation event

140 (Mayhew and Houston 1989) and consequently their feeding is restricted to strips of

141 vegetation near to the water. Distance from water and flock size were measured as

142 covariates indicating varying levels of risk (e.g. Mayhew 1987; Elgar 1989). Vigilance in

143 wigeons typically increases with distance foraging from water, and decreases with

144 increasing flock size (Mayhew and Houston 1989). Such a situation may alter the relative

145 importance of the male investment, male constraint and female benefits hypotheses

146 compared to other safety contexts.

147 We predicted that if increased vigilance in males is primarily related to predator

148 detection (the male constraint hypothesis), then (1) the amount of vigilance behaviour 
149 exhibited by both sexes should be similar before and after pairing, (2) vigilance should

150 decrease with increasing flock size at the same rate for both males and females, or at a

151 higher rate in the more conspicuous males, and (3) vigilance should increase with

152 increasing distance from water, again, at the same rate in males and females, or at a higher

153 rate in the more conspicuous males.

154 If mate guarding and paternity assurance plays a significant additional role in 155 vigilance (the male investment hypothesis), it was then predicted that (1) males should

156 become more vigilant than females in late winter, or the difference between males and

157 females should increase in late winter compared to early winter, (2) female vigilance

158 should remain constant or decrease in late winter (because they are being guarded by their

159 mate), and (3) male vigilance should increase with increasing flock size (because there are

160 more competing males), or remain similar if the benefits in terms of safety from predators

161 are counterbalanced by the costs in terms of sexual competition.

162 If the benefit to the female was the primary driving force of male vigilance (female

163 benefits hypothesis), it was predicted that (1) females should become less vigilant in late

164 winter compared to early winter as they are utilising their partners vigilance (2) male 165 vigilance should remain the same or increase in late winter compared to early winter, and

166 (3) vigilance should not be affected by group size or distance from water in either males or 167 females.

169 Methods

170 Study site

171 Traeth Lafan (Lavan Sands) is a large intertidal area of sand and mud flats lying on

172 the eastern edge of the Menai Straits, in Conwy Bay, North Wales, UK $\left(53^{\circ} 17^{\prime} \mathrm{N}, 4^{\circ} 16^{\prime}\right.$

$173 \mathrm{~W})$. The area as a whole has a range of exposures and a diversity of conditions enhanced 
174 by freshwater streams that flow across the flats, and covers a total area of 2,643 ha. The 175 area is well used by members of the public, and is bordered by a railway line and a series

176 of public footpaths. The majority of the wigeon flock frequents a small intertidal area

177 comprising Juncetum gerardii and Puccinellietum salt-marsh, approximately $1.5 \mathrm{~km}$ west

178 of the village of Llanfairfechan $\left(53^{\circ} 15^{\prime} \mathrm{N}, 4^{\circ} 1^{\prime} \mathrm{W}\right)$. The total number of wigeons present

179 each day varied between 180 - 440. Northern pintails Anas acuta regularly joined the

180 wigeon flock during grazing periods, along with lesser numbers of redshanks Tringa

181 totanus, Eurasian teals Anas crecca and mallards Anas platyrhynchos. There were no geese

182 or swans present. The main footpath that runs along the edge of the marsh and shoreline

183 experienced, on average, 37 human walkers along it per hour. Raptor flyovers were 2.9 and

1842.1 per hour, for the November and March sampling sessions respectively. The main raptor 185 species involved in this were peregrine falcons (Falco peregrinus) and common buzzards 186 (Buteo buteo), and less frequently, merlins (Falco columbarius), common kestrels (Falco tinnunculus) and on one occasion, hen harriers (Circus cyaneus).

Vigilance recording

Wigeon were counted and observed using an Opticron telescope (30x) and Opticron

191 binoculars $(10 \times 50)$. Observations were conducted from the $12^{\text {th }}-25^{\text {th }}$ November, 2003,

192 and from the $4^{\text {th }}-16^{\text {th }}$ March, 2004. The individual pairing status of each bird could not be

193 recorded (see below), so it is possible that some individuals from the November sample

194 were already paired, and some late individuals from the March sample (especially

195 juveniles) were still unpaired. However, November is when wigeons start to pair in

196 significant numbers (Guillemain et al. 2003) and most of these are generally paired by the

197 end of winter (Mayhew and Houston 1989), so that the two study periods were assumed to

198 adequately represent the pre- and post-pairing periods. A total of 562 focal observations 
199 (sensu Altmann 1974) were used in the analyses, 244 in November and 318 in March.

200 Ducks were not individually marked, and it is therefore possible that some of them may

201 occasionally have been sampled twice. However, the incidence of double sampling during

202 the same day is likely to be low (see below), and thus should not cause an important

203 problem for statistical analyses. The traditionally high turnover of individuals among

204 wintering duck populations (Pradel et al. 1997, Guillemain et al., 2010) also made the

205 double sampling of the same birds over different days unlikely. Counts were made during

206 daylight within 1.5 hours of low tide, for a total period of three hours - typically 1.5 hours

207 either side of low tide. Observations were made from a bench overlooking the tidal salt

208 marsh area, approximately 100 metres away from the region the wigeon most frequently

209 grazed. Because the birds formed many small groups, it was possible to get a large sample

210 number of many different flock sizes, and also limited the risk of sampling the same

211 individual more than once.

212 Sampling protocol followed that of Mayhew (1987) and Guillemain et al. (2002).

213 One focal bird was randomly selected from the approximate centre of the flock, sexed and

214 observed for 300 seconds. So as to provide an approximate equal number of each sex,

215 different sexes were observed alternatively, i.e. if the randomly selected individual was of

216 the 'wrong' sex, then the nearest bird of correct sex to this random one was observed

217 (Mayhew 1987).

218 Vigilance was measured as \% time with head up in a grazing bird (i.e. grazing was

219 its predominant activity). At the start and end of each $300 \mathrm{~s}$ observation period, the flock

220 size was recorded and for each observation, a mean flock size allocated. The same

221 principle was applied to flock distance from water. The distances were estimated by eye, in

222 metres, but were considered to be reasonably accurate since the length of the area between

223 the footpath where the observations took place and the low tide of the water was known 
224 (Mayhew and Houston 1989). The wigeon typically fed in compact, closely-knit groups in 225 the winter. However, at times there were a few individuals more widely dispersed. In order 226 to restrict the observations to birds feeding in clearly defined groups, birds further than 20 227 metres from the centre of the flock were not included in the estimation of flock size, or 228 selected for any vigilance recordings (Mayhew and Houston 1989). As the focus was on 229 one bird at a time (i.e. one bird typically filled the eyepiece of the telescope), it was not 230 possible to accurately determine whether each bird was paired or not. The maximum flock 231 size recorded during the sampling session was 350, and the maximum distance the wigeons 232 foraged from the waters edge was 35 metres.

Statistical Analysis

We used General Linear Models (GLM) to test for differences in proportion of time spent vigilant by focal birds (arcsin-transformed during the statistical analyses, but presented as percentages in the figures to ease reading) between sexes and periods of the 238 winter, taking into account the potential effects of distance from water and flock size. 239 Preliminary analyses suggested a non-linear relationship between vigilance rate and flock 240 size, so the latter was log-transformed before inclusion in the models. Similarly, a 241 significant correlation was initially found between flock size (log-transformed) and 242 distance from water $(P<0.0001)$. However, the regression coefficient was relatively low $243\left(r^{2}=0.55\right)$, so that there was some variability in flock size that was not explained by 244 variability in distance. In order to tease apart the relative role of each variable on wigeon 245 vigilance (i.e., flock size and distance from water), both were therefore included at the 246 beginning of the model selection procedure. The variables and factors initially entered into 247 the GLM were, therefore, Sex, Month, Distance from water (hereafter "Distance"), $248 \log ($ FlockSize), and all possible interactions with up to three terms (the biological 
meaning of more complicated models being difficult to interpret). A stepwise backwards model selection procedure was then used, where non significant terms at $P=0.05$ were gradually removed, starting with the most complex interactions. All values are presented as means \pm SE. All tests are considered significant if $P<$ 2530.05.

\section{Results}

The final model of the stepwise procedure provided an excellent fit to the data $\left(r^{2}=\right.$

0.91; Table 1). It first highlighted the major role of danger in itself on individual vigilance rate, $\log ($ FlockSize $)$ alone being responsible of $75 \%$ of the explained variance (see ratio of partial F-values from Table 1). Males were generally more vigilant than females, and increased their vigilance rate from November to March, though to a limited extent $(11.82 \%$

$261 \pm 0.54, \mathrm{n}=149$ and $13.25 \% \pm 0.58, \mathrm{n}=131$ ), while that of females decreased twice as much $(10.58 \% \pm 0.41, \mathrm{n}=138$ and $7.62 \% \pm 0.42, \mathrm{n}=135 ;$ Fig. 1$)$.

The two sexes fed in flocks of similar size both in November (ANOVA: $F_{1,285}=$ $\left.2640.02, r^{2}=0.00, P=0.8848\right)$ and in March (ANOVA: $\mathrm{F}_{1,264}=0.77, r^{2}=0.00, P=0.3819$ ). 265 The differences in vigilance rates between the two time periods could not be explained by average flock size being different between November and March in either of the two sexes (ANOVA on average $\log \left(\right.$ FlockSize): Males: $\mathrm{F}_{1,278}=0.58, r^{2}<0.01, P=0.4485$; Females $\left.\mathrm{F}_{1,271}=3.03, r^{2}=0.01, P=0.0830\right)$. However, there was a significant effect of the

269 Sex*Log(FlockSize), the Month*Log(FlockSize) and the Sex*Month*Log(FlockSize) interactions (Table 1) indicating that, despite average flock sizes being similar in all cases,

271 i) vigilance decreased at a higher rate with increasing flock size in males than in females,

272 ii) vigilance decreased at different rates in November and in March, and iii) the later 273 difference was of different magnitude between males and females. In the later case, the 
negative slope of vigilance rate against flock size actually increased in magnitude from

275 November to March in males, and decreased in females (Fig. 2).

Males increased their foraging distance from water between the two time periods $\left(10.84 \mathrm{~m} \pm 0.54\right.$ and $13.79 \mathrm{~m} \pm 0.57$ in November and March, respectively; ANOVA: $\mathrm{F}_{1,278}$

$\left.278=13.99, r^{2}=0.05, P=0.0002\right)$, while females showed an opposite trend $(11.34 \mathrm{~m} \pm 0.58$

279 and $7.93 \mathrm{~m} \pm 0.58$, respectively; ANOVA: $\left.\mathrm{F}_{1,271}=17.39, r^{2}=0.06, P<0.0001\right)$. While males and females fed at a similar distance from water in November $\left(\right.$ ANOVA: $\mathrm{F}_{1,285}=$ $\left.2810.45, r^{2}=0.00, P=0.5043\right)$, females thus fed at a shorter distance from water than males in March (7.93 $\mathrm{m} \pm 0.60$ and $13.79 \mathrm{~m} \pm 0.61$, respectively; ANOVA: $\mathrm{F}_{1,264}=46.70, r^{2}=0.15$ $P<0.0001)$. In March, males spent, on average, $25 \%$ of their time being vigilant when

284 foraging in small flocks (Fig. 2) compared to 15\% of their time in November. Comparably, time spent being vigilant by females in November when foraging in small flocks, as with the males, was approximately $15 \%$, reducing to $10 \%$ in March. benefit birds gained from foraging closer to the water in terms of decreased vigilance was

289 similar in males and females, and did not differ between the two time periods, that is, the slopes remained similar.

\section{Discussion}

Our data provides little support for the male investment hypothesis (Guillemain et al. 2003), that males increase their vigilance to guard their mate when they become paired.

295 Even the slight increase in male mean vigilance from November to March could be simply explained by non-mating reasons since males, on average, fed at a greater distance from water in March. In both sexes, vigilance increased with foraging distance from water and

298 decreased with increasing flock size. We have shown that wigeons on our wetland study 
site spent a $c .10 \%$ of their potential feeding time scanning their environment. This is similar to what wigeons have been recorded to do when foraging on dry land previously

301 (Guillemain et al., 2002 or Mayhew 1987). For comparison, female and unpaired male 302 wigeons on average spent less than $5 \%$ of their time vigilant while foraging on the Exe 303 Estuary, where males were apparently essentially vigilant to ensure paternity with their 304 mate and for pair bond protection (Guillemain et al. 2003). Compared to Mayhew and 305 Houston (1989), the wigeons in the current study foraged, on average, in larger flocks and 306 closer to the water. For example, at Caerlaverock, Solway Firth (Mayhew and Houston, 307 1989), the wigeons maximum foraging distance from the water was 60 metres, compared 308 to just 35 metres in the present study. This can be attributed to the smaller site in the 309 present study when compared to Caerlaverock. The total distance from the high tide line of 310 the sea to the footpath at the rear of the marsh was only approximately 80 metres. 311 Therefore, the wigeons were foraging at smaller distances from a water body, whether that 312 is the sea or one of the many small pools that were present within the marsh.

313 Male vigilance increased markedly in more risky situations (smaller groups, longer 314 distance from water), and only changed to a minor extent from the pre- to the post-mating 315 periods. Moreover, male and female vigilance was similar in the November period. This 316 suggests that the slightly higher vigilance rate of males during March compared to that of 317 females is not a result of the male constraint hypothesis (it is not related to the male's 318 plumage). The vigilance patterns are consistent with the predicted commonly observed 319 relationship between vigilance and distance from water or group size in wigeons (Mayhew 320 1987; Mayhew and Houston 1989). The increase in foraging distance during late winter in 321 the males supports the hypothesis that anti-predator vigilance plays a major role in the 322 behaviour of wigeons when in foraging flocks. It is highly likely that males are forced to 323 use these distant and more risky areas in late winter, when safer feeding patches closer to 
water have been depleted (following general central-place foraging theory, e.g. Stephens and Krebs 1986). The significant decrease in female vigilance between the two periods and the lack of a similar increase in male mean vigilance (the difference in vigilance rates was twice larger in females than in males) lends support to the female benefits hypothesis. Females fed closer to the water in March than in November, i.e. were less at risk when they were paired. Examination of Figure 2 shows that females decreased their vigilance from November to March when they were foraging in the most risky situations, i.e. when in smaller flocks. Male vigilance was maximum in such situations, and almost twice that of females: in flocks of 3-5 birds males spent $20.4 \%$ of their time vigilant $( \pm 0.5, \mathrm{n}=53)$, while females spent $11.7 \% \pm 0.5(\mathrm{n}=51)$. Paired females in March will thus benefit from the presence of their mate in such most risky situations, enabling them to continue foraging and build body stores.

The female benefits hypothesis provides a satisfactory evolutionary framework for vigilance patterns in paired birds, as the effectiveness of mate guarding has been called into question (Struchbury and Neudorf 1998), mainly because of time constraints on the male, and the tactics that females can adopt to circumvent male guarding efforts. However, it has been shown that mate guarding can be effective in partially assuring paternity, particularly when males are extremely attentive (ChuangDobbs et al. 2001). For example, male common eiders spend $99 \%$ of their time mateguarding when the females are most fertile (Christensen 2000; Hario and Hollmén 2004). However, male birds of other species continue to follow females after the fertile period has ended, suggesting that paternity assurance is not the primary reason for general mate-guarding, and increased vigilance (Squires et al. 2007; Rodway 2007a). Martin et al. (2003) proposed that predation risk was more important than partial loss of paternity, as a fatal attack on a female will result in a total loss of 
349 offspring. It is, therefore, better for the male to invest in the female through allowing 350 her to feed at a higher rate than she would otherwise, and thus allowing the male to 351 potentially increase his own fitness. Quan et al (2003) suggested that male birds could 352 also achieve this through maintenance of the pair bond and female preference. The 353 question still remains, however, of whether females simply capitalise on male 354 vigilance or stimulate it (Artiss et al. 1999). A recent theory encompasses benefits for 355 both males and females. Rodway (2007a, 2007b) studied the time unpaired male 356 harlequin ducks spent engaged in display behaviour, which was mutually exclusive to 357 foraging. When the males became paired, they significantly reduced displaying 358 behaviour and increased foraging, thus increasing their energy intake. Simultaneously, 359 the females also increased foraging (Rodway 2007a; Rodway 2007b). Therefore, both 360 the male and female mutually benefit from pairing in terms of time-budget. However, 361 it has been proposed that the female should only pair early if the bond is beneficial for 362 her (Artis and Martin 1995). If food is plentiful and predation risk low, the female 363 should actually avoid the more conspicuous males (Artis and Martin 1995; Rodway 364 2007b). In wigeons, it is likely that as the wintering season progresses, food and 365 resources will be further from the water (see above) and thus involves riskier 366 foraging. Therefore, pairing up at this stage would be a good strategy for the female.

367 Both the male and female benefit from the female being in the best possible 368 physiological condition.

369 That males responded to group size more than females (they decreased their 370 vigilance to a greater extent with increasing group size), and did so to a higher extent in 371 March than in November (while the reverse would have been expected if there was a fierce 372 competition for females between males) suggests that the increase in male vigilance, 373 particularly in small flocks, is for the benefit of the female. If this increase vigilance was 
anti-predator related, the relationships between male vigilance and flock size would be expected to remain unchanged between November and March. Because the present terrestrial feeding location is intrinsically dangerous (Mayhew 1988; Mayhew and Houston 1989; Larsen 1996), vigilance levels in male wigeon are particularly high in Traeth Lafan, even in November. Once mated, the paired females are benefiting from this genuine high level of vigilance by their mate to decrease their own vigilance and dedicate more time to foraging (see also Jacobsen and Ugelvik 1994).

What is unusual is the lack of a large increase in male vigilance when paired (e.g., Martin 1984, Guillemain et al. 2003). From our data set, it is not possible to determine whether males could increase their vigilance further at Traeth Lafan. It is likely male wigeons at Traeth Lafan are already close to the maximum vigilance level they can afford to be without compromising their daily energy intake. In this scenario, females are able to benefit from the males vigilance at now extra cost to the male, and the males only need provide minimal supplementary vigilance in late winter. This, coupled with already high levels of vigilant behaviour in males means the females are able reduce their vigilance and

389 focus on foraging. This occurs with no detriment to the male's daily energy intake. The 390 only circumstance where this may alter is when foraging in small flocks, when males are 391 both significantly more vigilant than females and more vigilant than when foraging at the 392 same distance in early winter compared to late winter. If mate guarding and paternity 393 assurance can be ruled out as a function of vigilance in the present study, paired males and 394 females could potentially benefit from foraging in larger flocks to avoid the male having to 395 increase vigilance.

The present pattern would thus be similar to the situation recorded in Eurasian teal

397 foraging at deep depths, where males are already so vigilant because of their blind 398 exposure to predators when up-ending to forage that they do not increase vigilance after 
acquiring a mate (Guillemain et al. 2007b). In both cases, this could explain how male

400 birds with high energy demands can afford the cost of maintaining a pair-bond during such

401 long periods in winter (see Rodway 2007b). Data are not available at present, but a 402 comparison of forced copulation attempts on female wigeons at Traeth Lafan and on the 403 Exe Estuary (where male wigeons are clearly vigilant for paternity assurance and/or pair404 bond protection) could allow testing the above hypothesis more specifically. This study, 405 therefore, suggests that whether male and female vigilance in a given species is more likely 406 to be driven by the male constraint, male investment or female benefits hypothesis may 407 depend very much upon the environmental safety conditions, and is not a fixed species408 specific life history trait. While they had long been considered as mutually exclusive 409 activities, the traditional distinction between non-vigilant feeding bouts and non-feeding 410 vigilance bouts in foragers was challenged a few years ago by Lima and Bednekoff (1999), 411 showing that some individuals were able to maintain anti-predator vigilance while foraging 412 with their head down. Similarly, the present study suggests that vigilance for several 413 purposes may be combined by paired males in some situations.

Acknowledgements

416 We are grateful to Nigel Brown for assistance during the planning of the fieldwork, and to 417 David Gardiner for logistical support. Graham Martin, Jon Green and an anonymous 418 referee provided useful comments on an earlier version of the manuscript. We are also 419 grateful to the numerous students, particularly Tom Richardson, who assisted with 420 fieldwork, and to Claire Tyler and Craig White for useful discussions.

421 The authors declare that they have no conflict of interest. 
426 Altmann, J. (1974) Observational study of behaviour: sampling methods. - Behaviour. 49: $427 \quad 227-267$.

428 Artis, T., Martin, K. (1995) Male vigilance in white-tailed ptarmigan, Lagopus

429 leucurus: mate guarding or predator detection? - Anim. Behav. 49: 1249-1258.

430 Artiss, T., Hochachka, W.M. \& Martin, K. 1999. Female foraging and male vigilance in 431 white-tailed ptarmigan (Lagopus leucurus): opportunism or behavioural coordination ? 432 Behav. Ecol. Sociobiol. 46: 429-434.

433 Ashcroft, R.E. (1976) A function of the pairbond in the common eider. - Wildfowl. 27: 434 101-105.

435 Baldassarre, G. A., Bolen, E. G. (2006) Waterfowl Ecology and Management. John Wiley 436 and Sons, INC., New-York, USA.

437 Black, J. M. (2005) Ecology of social behaviour. In: Kear, J. (ed). Ducks, geese and swans. 438 Oxford University Press, Oxford, UK. pp 57-67.

439 Bowler, J. (2005) Breeding strategies and biology. In: Kear, J. (ed). Ducks, geese and 440 swans. Oxford University Press, Oxford, UK. pp 68-111.

441 Choudhury, S. and Black, J. M. (1993) Mate selection behaviour and sampling 442 strategies in geese. - Anim. Behav. 46: 747-757.

443 Christensen, T. J. (2000) Female pre-nesting foraging and male vigilance in Common 444 Eider, Somateria mollissima. - Bird Study. 47: 311-319

445 Chuang-Dobbs, H. C., Webster, M. S., Holmes, R. T. (2001) The effectiveness of 446 mate guarding by male black-throated blue warblers. - Beh. Ecol. 12: 541-546.

447 Dahlgren, J. (1990) Females choose vigilant males: an experiment with the monogamous 448 grey partridge, Perdix perdix. - Anim Behav. 39: 646-651.

449 Elgar, M. A. (1989) Predator vigilance and group size in mammals and birds: a critical 450 review of the empirical evidence. - Biol. Rev. 64: 13-33.

451 Gauthier, G. (1987) The adaptive significance of territorial behaviour in breeding 452 buffleheads: a test of three hypotheses. - Anim. Behav. 35: 348-360.

453 Goodburn, S. F. (1984) Mate guarding in the mallard, Anas platyrhynchos. - Orn. Scand. 454 15: 261-265.

455 Guillemain, M., Martin, G. R., Fritz, H. (2002) Feeding methods, visual fields and 456 vigilance in dabbling ducks (Anatidae). - Funct. Ecol. 16: 522-529.

457 Guillemain, M., Caldow, R. W. G., Hodder, K. H., Goss-Custard, J. D. (2003) Increased 458 vigilance of paired males in sexually dimorphic species: distinguishing between alternate 
459 explanations in wintering Eurasian wigeon. - Beh. Ecol. 14 (5): 130-135. DOI:

$460 \quad 10.1093 /$ beheco/arg060

461 Guillemain, M., Lepley, M., Fritz, H., Hecker, N. (2007a) Marsh Harriers Circus 462 aeruginosus target Teals Anas crecca at roosts according to potential availability of 463 vulnerable prey not total availability. - Bird Study. 54: 268-270.

464 Guillemain, M., Arzel, C., Legagneux, P., Elmberg, J., Fritz, H., Pin, C., Arnaud, A., 465 Massez, G. (2007b) Risky foraging leads to cost-free mate guarding in male teal, Anas 466 crecca. - J. Ornithol. 148: 251-254. DOI: 10.1007/s10336-006-0120-2

467 Guillemain, M., Elmberg, J., Arzel, C., Johnson, A.R., Simon, G. (2008) The income468 capital breeding dichotomy revisited: late winter body condition is related to breeding 469 success in an income breeder. - Ibis. 150: 172-176.

470 Guillemain, M., Devineau, O., Brochet, A.L., Fuster, J., Fritz, H., Green, A.J. \& Gauthier471 Clerc, M. 2010. What is the spatial unit for a wintering teal Anas crecca? Weekly day roost 472 fidelity inferred from nasal saddles in the Camargue, southern France. Wildlife Biol. - 16: $473 \quad 215-220$.

474 Hart, P. J. and Freed, L. A. (2004) Predator avoidance as a function of flocking in the 475 sexually dichromatic Hawaii akepa - Ethol. 23: 29-33.

476 Hario, M., Hollmén, T. E. (2004) The role of mate-guarding in pre-laying common 477 eiders (Somateria mollisima) in the northern Baltic Sea. - Ornis Fenn. 81: 119-127.

478 Jacobsen, O. W., Ugelvik, M. (1994) Effects of waders on grazing and vigilance in 479 breeding wigeon, Anas penelope. - Anim. Behav. 47 (2): 488-490.

480 Johnson, W. P., Rohwer, F. C. (1998) Pairing chronology and agonistic behaviors of 481 wintering Green-winged Teal and Mallards. - Wilson Bull. 110: 311-315.

482 Krebs, J.R., Davies, N.B (1993) An introduction to Behavioural Ecology. Third Edition. 483 Blackwell Science, Oxford.

484 Lamprecht, J. (1989) Mate guarding in geese: awaiting female receptivity, protection of 485 paternity or support of female feeding? In: Rasa, A. E., Vogel, C., Voland, E. (eds). The 486 socio-biology of sexual and reproductive strategies. Chapman and Hall, London, pp. 48-60. 487 Larsen, J. K. (1996) Wigeon Anas penelope offsetting dependence on water by feeding in 488 mixed-species flocks: a natural experiment. - Ibis. 138: 555-557.

489 Lendrem, D. W. (1983) Sleeping and vigilance in birds. 1. Field observations of the 490 mallard (Anas platyrhynchos) - Anim, Behav. 31: 532-538. 
491 Lercel, B. A., Kaminski, R. M., Cox, R. R. (1999) Mate loss in winter affects reproduction 492 of Mallards. - J. Wildlife Manage. 63: 621-629.

493 Lima, S. L. (2009) Predators and the breeding bird: behavioural and reproductive 494 flexibility under the risk of predation. - Biol. Rev. 84: 485-513.

495 Lima, S.L., Bednekoff, P.A. (1999) Back to the basics of antipredator vigilance: can 496 nonvigilant animals detect attack? - Anim. Behav. 58: 537-543.

497 Martin, K. (1984). Reproductive defense priorities of male willow ptarmigan 498 (Lagopus lagopus) - enhancing mate survival or extending paternity options? - Beh. 499 Ecol. Soc.

500 Martin, K., Holt, R. F., Thomas, D. W. (1993) Getting by on high: ecological 501 energetics of arctic and alpine grouse. In Life in the Cold: Ecological, Physiological 502 and Molecular Mechanisms (Ed. By C. Carey, G. L., Florant, B. A. and B. Horwitz), 503 pp. 33-41. Boulder, Colorado: Westview Press.

504 Mayhew, P. W. (1987) Vigilance levels in European Wigeon, Anas penelope - sexual 505 differences. - Wildfowl. 38: 77-81.

506 Mayhew, P. W. (1988) The feeding ecology of wigeon. Wigeon-current trends and future 507 needs (ed J. Harradine), pp 31-41. The British Association for Shooting and Conservation, 508 Rossett, UK.

509 Mayhew, P. W., Houston, P. W. (1989) Feeding site selection by Eurasian wigeon, Anas 510 penelope in relation to water. - Ibis. 131 (1): 1-8.

511 Mitchell, C. (1997) Re-mating in migratory Wigeon Anas penelope. - Ardea 85: 275-277.

512 Oring, L. W., Sayler, R. D. (1992) The mating systems of waterfowl. Ecology and 513 Management of breeding waterfowl (ed B. D. J. Batt, A. D. Afton, M. G. Anderson, C. D. 514 Ankney, D. H. Johnson, J. A. Kadlec and G. L. Krapu), pp 190-213. University of 515 Minnesota Press, Minneapolis, USA.

516 Pizzaro, T. (2003) Food, vigilance and sperm: The role of male direct benefits in the 517 evolution of female preference in a polygamous game bird. - Behav. Ecol. 14: 593518601.

519 Pradel, R., Hines, J. E., Lebreton, J-D., Nichols, J. D. (1997) Capture-recapture survival 520 models taking into account of transients. - Biometrics. 53: 60-72.

521 Quan, R. C., Cui, L. W., Wen, X. J. (2003) Sexual differences of paired ruddy 522 shelduck in winter. - Waterbirds. 26: 335-337.

523 Rodway, M. S. (2007a) Timing of pairing in waterfowl I: Reviewing the data and 524 extending the theory. - Waterbirds. 30: 488-505. 
525 Rodway, M. S. (2007b) Timing of pairing in waterfowl II: testing the hypothesis with 526 harlequin ducks. - Waterbirds. 30: 506-520.

527 Rohwer, F. C., Anderson, M. G. (1988) Female-biased philopatry, monogamy, and the 528 timing of pair formation in migratory waterfowl. Current Ornithology Vol. 5 (ed R. F. 529 Johnston), pp. 187-221. Plenum Press, New-York, USA.

530 Squires, K. A., Martin, K., Goudie, R. I. (2007) Vigilance behaviour in the harlequin 531 duck (Histrionicus histrionicus) during the preincubation period in Labrador: Are 532 males vigilant for self or social partner? - Auk. 124: 241-252.

533 Stephens, D. W., Krebs, J. R. (1986) Foraging theory. Princeton university press, 534 Princeton, New Jersey. 247pp.

535 Struchbury, B. J. M., Neudorf, D. L. (1998) Female control, breeding synchrony, and 536 the evolution of extra-pair mating systems. In: Avian reproductive tactics: female and 537 male perspectives, Ornithological Monographs no. 49 (Parker PG, Burley NT eds). 538 Washington, DC: American Ornithological Union; 103-123.

539 Thomas, V. G. and Popko, R. (1981) Fat and protein reserves of wintering and 540 prebreeding rock ptarmigan from south Hudson Bay. - Can. J. Zool. 59: 1205-1211

541 Torres, R. F., Cooke, G. J., Roberston, G. J. and Boyd, W. S. (2002) Pairing decision 542 in the harlequin duck: costs and benefits. - Waterbirds. 25: 340-347.

543 Wiebe. K. and Martin, K. (1998) Age-specific patterns of reproduction in white-tailed 544 and willow ptarmigan, Lagopus leucurus and Lagopus lagopus. - Ibis. 140:14-24.

545 Wittenberger, J. F. and Tilson, R. L. (1980) The evolution of monogamy: hypotheses 546 and evidence. - A. Rev. Ecol. Syst. 11: 197-232. 
550 Fig. 1 Average percentage of time spent vigilant by male and female wigeon in November

551 and March. Vertical bars show standard errors, numbers in brackets are sample sizes. See 552 text for statistics.

553

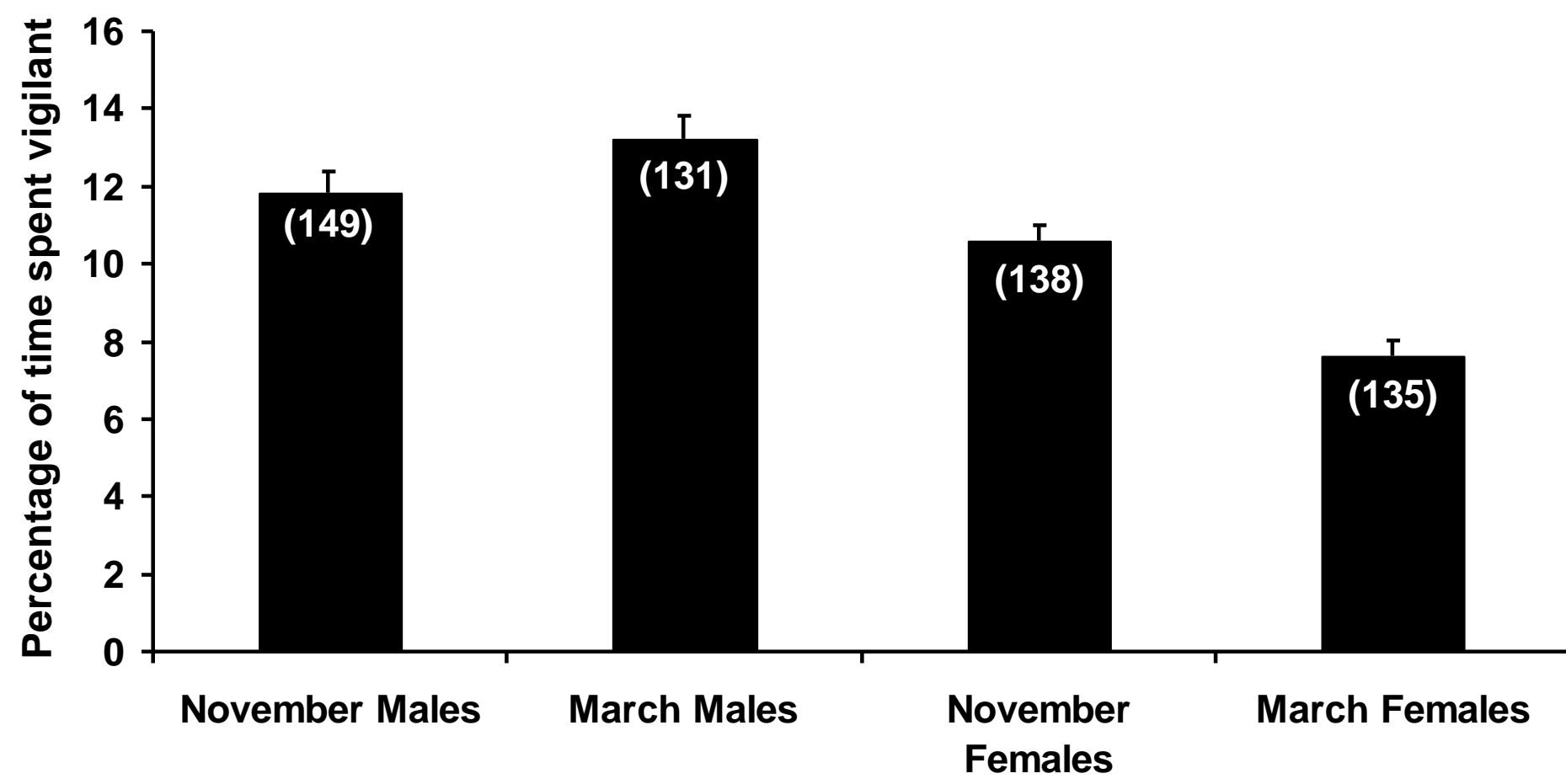


555 Fig. 2 Percentage of time spent vigilant by male (top) and female (bottom) wigeon as a 556 function of flock size (Log-transformed) during the two study periods. November data are

557 represented by black dots and plain lines, March data by white circles and dotted lines. See 558 text for statistics.

559
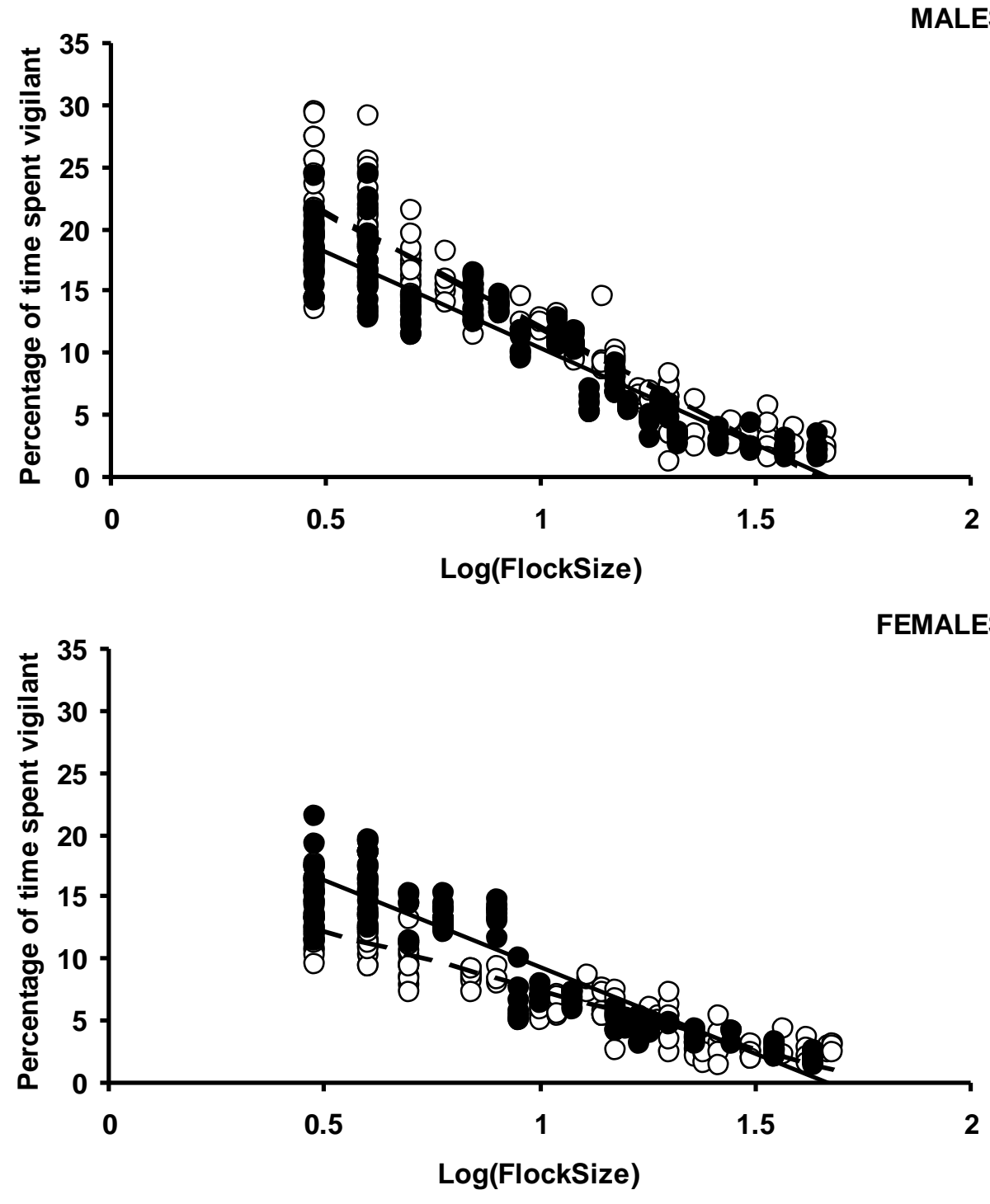
561 Table 1 Best fitting models for the percentage of time spent vigilant by wigeon while

562 foraging, testing for differences between males and females (Sex), November and March

563 observation periods ("Month"), the effect of group size in which each focal bird foraged

564 ("Log(FlockSize)") and the distance from water at which it did so ("Distance"), plus their

565 interactions. Only the final model of the backwards stepwise model selection procedure is

566 shown.

567

\begin{tabular}{lllll}
\hline \multicolumn{1}{c}{ Variable } & df & \multicolumn{1}{c}{ Estimate \pm SE } & Partial F & P-Value \\
\hline & Complete model: & $\boldsymbol{F}_{\boldsymbol{8 , 5 4 4}}=\mathbf{7 1 0 . 2 4}, \boldsymbol{r}^{\mathbf{2}}=\mathbf{0 . 9 1 , ~} \boldsymbol{P}<\mathbf{0 . 0 0 0 1}$ & \\
\hline Sex (Males) & 1 & $2.93 \pm 0.21$ & 194.02 & $<0.0001$ \\
Month (March) & 1 & $-0.64 \pm 0.21$ & 9.35 & 0.0023 \\
Log(FlockSize) & 1 & $-12.00 \pm 0.31$ & 1471.82 & $<0.0001$ \\
Distance & 1 & $0.18 \pm 0.02$ & 114.63 & $<0.0001$ \\
Sex*Month & 1 & $1.68 \pm 0.21$ & 61.09 & $<0.0001$ \\
Sex*Log(FlockSize) & 1 & $-1.81 \pm 0.21$ & 75.66 & $<0.0001$ \\
Month*Log(FlockSize) & 1 & $0.59 \pm 0.21$ & 8.10 & 0.0046 \\
Sex*Month*Log(FlockSize) & 1 & $-1.15 \pm 0.2112$ & 30.55 & $<0.0001$ \\
\hline
\end{tabular}

568

569

570

571

572

573

574 